\title{
Ev Restorancılığının Destinasyona Yönelik Kazanımlarının Paydaş Görüşleri Açısından Değerlendirilmesi
}

\author{
Evaluation of Destination Gains from Home Restaurant in terms of Stakeholder View
}

\author{
Sedat ŞAHİN* Seda İDIKUT ŞAHİN**
}

\begin{abstract}
* Dr. Öğr. Üyesi, Van Yüzüncü Yıl Üniversitesi, Turizm Fakültesi, Turizm İsletmeciliği Bölümü, Van, Türkiye.

** Necmettin Erbakan Üniversitesi, SBE, Turizm İşletmeciliği ABD, Konya, Türkiye.
\end{abstract}

\section{ORCID}

S.Ş.: 0000-0003-0167-101X (iD)

S.İ.Ş: 0000-0002-8230-7238 (D)

Corresponding Author:

Sedat ŞAHIN

Email

sedatsahin@yyu.edu.tr

\section{Citation:}

Şahin, S. ve İdikut Şahin, S., (2020). Ev Restorancılığının Destinasyona Yönelik Kazanımlarının Paydaş Görüşleri Açısından Değerlendirilmesi, Journal of Academic Tourism Studies, 1(1): 19-29.

\section{Özet}

Ev restorancılığı, bă̆ımsız ev sahiplerinin şehirlerini ziyaret eden turistleri evlerinde ağırlayarak yeme-içme hizmeti sunduğu bir konsept olarak açıklanabilir. Dolayısıyla, ziyaretçilerin seyahat ettikleri destinasyonlar konusunda doğrudan ve daha detaylı bilgi edinebileceği bir deneyim olarak görülebilir. Destinasyonlar açısından da yeni hizmet türleri ortaya koyma ve farklılaşma stratejileri, rekabet üstünlüğü sağlama konusunda son derece önemlidir. Ziyaretçilere yeni bir deneyim sunmak da bu bağlamda önemli bir çekicilik olarak değerlendirilebilecektir. Bu düşünceden hareketle bu araştırmada ev restoranciliğının bir turistik ürün olarak sunulması durumunda ortaya çıkabilecek destinasyon kazanımlarına ilişkin paydaş görüşlerinin değerlendirilmesi amaçlanmıştır. Araştırma kapsamında nitel araştırma yöntemlerinden görüşme tekniği kullanılmıştır. Çalışmanın uygulama alanı olarak kendine has karakteristik özelliğe sahip olan ve yeme içme kültürü açısından zengin olduğu düşünülen Van ili seçilmiştir. Destinasyondaki karar vericilerden oluşturulan 6 kişilik çalışma grubu ile çalışma gerçekleştirilmiştir. Araştırma sonuçlarına göre ev restorancılı̆̆ının özellikle destinasyon tanıtımı açısından önemli bir çekicilik unsuru olabileceği tespit edilmiştir. Diğger bir önemli sonuca göre de ev restoranciliğının özellikle yerel kültürün tanıtımına ve aynı zamanda korunmasına önemli katkılar sunacağından bahsetmek mümkündür.

Anahtar Kelimeler: Ev Restorancılı̆̆ı, Destinasyon Kazanımı, Paydaşlar

\section{Abstract}

Home restaurant management can be explained as a concept where independent hosts host tourists visiting their cities and offer catering services. Therefore, it can be seen as an experience where visitors can obtain direct and more detailed information about the destinations they travel to. In terms of destinations, introducing new types of services and differentiation strategies are extremely important in providing competitive advantage. Offering a new experience to visitors can be considered as an important attraction in this context. Based on this idea, this study aimed to evaluate the stakeholder views on the destination gains that may arise if home restaurant is presented as a tourist product. Interview technique, one of the qualitative research methods, was used within the scope of the research. Van province, which has its own characteristics and is thought to be rich in food and beverage culture, was chosen as the application area of the study. The study was carried out with a 6-person working group composed of decision makers in the destination. According to the results of the research, it has been determined that home restaurant business can be an important attraction 
factor, especially in terms of destination promotion. According to another important result, it is possible to mention that home restaurant business will contribute significantly to the promotion and protection of local culture.

Keywords: Home Restaurants, Destination Gain, Stakeholders

\section{GİRIŞ}

Destinasyonlar için en büyük sorunlardan biri sınırlı sayıda turistik ürüne sahip olmaktır. Destinasyonlardaki turistik ürünler doğal kaynaklardan sağlanan ürünler olabildiği gibi destinasyon yönetimlerince gerçekleştirilen etkinlikler, uygulamalar veya yapay ürünler de olabilmektedir. Doğal kaynaklar açısından zengin olmayan destinasyonlar, talep yaratmak ya da artırmak için turistlere sunabileceği farklı hizmetler geliştirmek durumundadır. Özellikle turistlerin istek ve beklentilerinin sürekli değişkenlik gösterdiği günümüzde benzer ürünlerin yerine daha yaratıcı ve ekstra deneyim sunan ürünlerin sunumu daha fazla önem kazanmaktadır.

Destinasyonlardaki tanıtım çalışmalarında en önemli aktörler genellikle destinasyon yöneticileri olmaktadır. Yöneticiler destinasyonun hedef pazardaki tanıtım çalışmalarını organize etmekte ve yeni pazarlara ulaşmaya çalışmaktadır. Tanıtım çalışmaları genellikle mevcut destinasyon ürünleri üzerinden gerçekleştirilmektedir. Destinasyon yöneticilerinin bu konudaki diğer bir görevi de mevcut ürünleri geliştirmek ve ziyaretçilere yeni ürünler sunabilmektir. Destinasyon yöneticilerinin teşviki ve eğitim çalışmaları ile ev pansiyonculuğu, el işçiliği (halı/kilim dokuma, seramik işçiliği, örgüler v.b.), yerel lezzetler (reçeller, kuru gidalar, organik sebze ve meyveler, v.b.) gibi yerel halkın doğrudan turizm faaliyetleri içerisinde yer almasını sağlayacak birçok farklı ürünün geliştirilmesi mümkündür. Yerel halkın turistik ürün üretim ve sunum sürecine dahil edilmesi aynı zamanda yerel kültürün de daha fazla sergilenmesini sağlamaktadır. Yerel halk ile ziyaretçilerin etkileşiminin artması bu açıdan önemli görülmektedir. Araştırmanın çıkış noktasını oluşturan ev restorancılığı bu deneyimi ziyaretçilerin yaşamasına ve kültürel kaynaşmaya olanak sağlamaktadır.

Ev restorancılığı, sınırlı sayıda turistin yeme içme ihtiyaçlarını yerel halktan birinin evinde karşılaması ve ev sahibinin de önceden hazırlamış olduğu menüyü müşterilerine kendi yaşadığı ortamın içerisinde sunması şeklinde gerçekleşen bir faaliyet olarak gerçekleşmektedir. Turistik ürün çeşitlendirmesi ile ilgili alan yazında yer alan bazı çalışmalar (Kılıç ve Kurnaz, 2010; Rotich, vd., 2012; Farmaki; 2012; Benur ve Bramwell, 2015; Purnomo, vd., 2018) destinasyonlarda yeni ürünlerin sürdürülebilir bir turizm için önemli bir avantaj olduğundan bahsetmektedir. Ev restorancılığının da bu açıdan değerlendirilme durumu araştırmanın çıkış noktasını oluşturmaktadır. Akademik olarak çok fazla tartışılmayan ev restorancılığı kavramının yaygınlaşmasının ve destinasyonlar tarafından bir turistik hizmete dönüştürülmesinin önemli olacağı düşünülmektedir. Dolayısıyla bu araştırma destinasyonlarda yeni bir hizmet fikri olarak ev restorancılığının uygulanabilirliğini ve destinasyona yönelik muhtemel kazanımlarını ortaya koymayı amaçlamaktadır. Bu amaç doğrultusunda destinasyon yöneticileri ve destinasyonda bu konuda karar verici konumda olan kişilerle görüşülerek elde edilen veriler değerlendirilmeye çalışılmıştır.

\section{DESTINASYON TANITIMI}

Destinasyonlarda tanıtım kavram olarak, yurt içi ya da yurt dışı pazarlarındaki potansiyel talebi destinasyonun ürünlerine ve hizmetlerine yöneltmek için, bilgi sunmak, teşvik etme, bir imajjn oluşmasını sağlamak aracılığıyla turistik ürünlerin ve hizmetlerin satın alımını kolaylaştıran yöntemleri içeren iletişim çabalarını ifade etmektedir (Karapınar, 2013: 4; Sheehan vd., 2007: 65; Therkelsen, 2003: 136). Diğer bir tanımda ise destinasyon tanıtımı, değerlerin duyurulması ve iletilmesi, vizyon ve destinasyonun rekabetçi özelliklerini tanıtması şeklinde açıklanmaktadır (Khan ve Karaoulanis, 2018: 3189). Buradan hareketle başarılı bir destinasyon tanıtımı yapmak isteyen yerel yönetimlerin turistik talebi korumak ve geliştirmek için fark yaratan yönlerini ortaya koymaları ya da yeni ürünler geliştirerek rekabet avantajı sağlamaları gerektiği söylenebilir. 
Destinasyon tanıtımı yalnızca turistleri bölgeye çekmek için değil aynı zamanda turistlerin destinasyonu deneyimlemeleri sırasında da devam eden bir süreçtir. Tanıtım araçlarının önemli unsurlarından biri olan tutundurma kavramı bu süreç içerisinde önemli rol oynamaktadır. Destinasyon deneyimlemesi sırasında ziyaretçi memnuniyetini etkileyen işletmeler, etkinlikler ve yerel halk gibi birçok unsur bulunmaktadır. Dolayısıyla destinasyon tanıtımı sürecinde en az destinasyon yöneticileri kadar söz konusu bu paydaşlara da görev düşmektedir. İşletmeler ve etkinlikler organizasyonel bir yapıya sahip olduğu için kontrol edilmesi ve geliştirilmesi yöneticilerin kontrolünde gerçekleşebilir. Fakat yerel halkın bu süreçte etkin olması için önemli bir halkla ilişkiler faaliyetine ihtiyaç vardır (Şahin ve İdikut Şahin, 2020: 208).

Destinasyon tanıtım çalışmaları açısından en önemli ortaklardan bir de yerel halktır (Kim vd., 2018: 583). Yerel halk tarafından turizm hareketliliğinin kabul edilmemesi ya da benimsenmemesi durumunda talebin geliştirilmesi veya turizm yatırımlanı yapmanın zor olacağı düşünülebilir. Dolayısıyla halkla ilişkiler çalışmaları yalnızca tutundurma faaliyetleri kapsamında değil yerel halka turizmin bölgesel etkilerini açıklama açısından da önemli aracılar olarak değerlendirilmelidir.

Diğer taraftan yenilikçi bir yaklaşım da destinasyon yönetimleri için mutlaka sahip olunması gereken bir anlayıştır (Paskaleva-Shapira, 2007: 109). Başarılı bir turizm yönetimi, ziyaretçilerin faydalanacağı ürün ve hizmetlerin geliştirilmesi, inovasyonu ve çeşitlendirilmesine bağlıdır (Echtner, 2010: 86; Grigorova, 2016:1). Destinasyonlarda yenilikçi bir yönetim anlayışı ziyaretçilere yeni ürün ve hizmetler sunarak gerçekleşebilir. Yeni ürün ve hizmetler geliştirmek ve sunmak potansiyel ziyaretçiler için yeni çekicilik niteliği taşırken destinasyonu sürekli ziyaret eden kişilerde de yeni heyecanların uyanmasını sağlayabilir.

\section{EV RESTORANCILIĞI}

New Tork'ta 2006 yılında başlayıp 2009 yılı ile İngiltere'de popüler olan ev restorancılığı trendi evde yemek yapmayı seven ve konusunda yetenekli kişilerin yemeklerini başka kişilere tattırmaya istekli ve buradan gelir elde etmeyi amaçlayan kişiler tarafından tercih edilen bir sistemdir. Ev restoranları ziyaret edilen bölgeyi keşfetmek için önemli aracı değerlerden biridir. Ev restorancılığı sistemindeki en önemli unsurlardan biri genellikle yerel lezzetlerin yerel malzemeler kullanılarak hazırlanıyor olmasıdır. Dünya genelinde otuz binden fazla ev restoranı olduğu tahmin edilmektedir. Evlerini ve mutfaklarını bir restorana dönüştüren ev sahipleri yerli ve yabancı ziyaretçilere veya gezginlere yöresel yemek kültürlerini, yaşadıkları şehrin özelliklerini ve yaşam tarzlarını sergileyerek bütüncül bir hizmet sunmaktadır (Dineaway, 2018). Yerel mutfak, destinasyonların anlamlı bir parçasıdır. Yalnızca gurmeler için değil aynı zamanda özgünlüğe ilgi duyan ve bir bölgenin kimliğini keşfetmekle ilgilenen daha büyük turist grupları için de yerel mutfakların önemi oldukça büyüktür. Hatta çoğu durumda bir gurme üst sınıf servis veren işletmeleri tercih ederken bir turist daha çok yerele inmeyi tercih edebilir (Gordin ve Trabskaya, 2013: 190).

Ev restorancılığı, bireylerin evlerinde ürettikleri menüleri çeşitli web siteleri aracılı̆̆ıyla destinasyonu ziyaret eden bireylere ulaştırdığı ve oluşan talep doğrultusunda ziyaretçileri evlerinde ağırlayarak bütüncül bir yeme-içme hizmeti sunduğu münferit bir organizasyon türüdür. Ev restorancllığının bir turistik ürün olarak tanımlanabilmesi için bu hizmeti talep edecek ziyaretçiler için belirli çekicilik unsurları taşıması gerekmektedir. Ziyaretçiler için ev restoranlarını deneyimlemenin avantajları şu şekilde sıralanabilir (Şahin ve İdikut Şahin, 2020: 210-211);

-Ev sahibinin ve dolayısıyla ilgili destinasyondaki varsa farklı yeme içme kültürünü yakından tanıma imkanı sağlar. Örneğin, Türkiye'de çoğu bölgede kebap bir lavaşa sarrlarak yenmektedir. 
- Bununla birlikte bu tür yemeklerde ziyaretçi tek başına yer almamaktadır. Farklı ülkelerden diğer ziyaretçilerle birlikte bu deneyimin yaşanması ziyaretçilere çok kültürlü bir ortam sunmaktadir.

-Yerel kültürü ve destinasyonu doğrudan tanıma fırsatı sunar. Yapılan sohbetler neticesinde bölgenin tarihi ve kültürel zenginliklerinin öğrenilmesinin yanında ziyaretçilere farklı bir ülkenin yemek kültürünü tanıma ve deneyimleme fırsatı sunmaktadir.

-Ziyaret edilen destinasyondaki aile yapısı ve yaşam biçimleri konusunda bilgi edinme fırsatı sağlamaktadır.

- Turistler genel olarak otellerde veya konaklama hizmeti sunan farklı işletmelerde konaklamaktadırlar. Dolayısıyla o şehirdeki mimari yapı konusunda yalnızca genel olarak bir fikir sahibi olabilirler. Destinasyonda yaşayan bireylerin evlerinin dizaynın nasıl olduğu gibi bilgilere ulaşmak zordur. Ev restorancılığı yeme içme deneyiminin yanında bunun gibi de birçok firsat sunmaktadır.

Birer işletme olarak ev restoranlarının bireyler tarafından şahsi ve tekil birer girişim olarak gerçekleştirildiğinden bahsedilebilir. Fakat bu tür işletmelerin hem yerel halka ekonomik olarak katkı sağlamak hem de yeni bir hizmeti turistlere sunmak açısından destinasyon yönetimleri tarafından hayata geçirilmesi önemli görülebilir. Söz konusu uygulamanın her yerde görülmemesi nedeniyle aynı zamanda bir çekicilik unsuru olacağı da belirtilebilir. Konuya bu açıdan ve ev restorancılığının ziyaretçilere sunduğu avantajlar açısından yaklaşıldığında aslında destinasyon ile ilgili birçok unsurun tanıtıldığı bir ortamın oluştuğundan bahsedilebilir.

\section{DESTINASYON TANITIMINDA EV RESTORANCILIĞI}

Destinasyonların rakipleri ile rekabet edebilmesi adına destinasyonun tamamını bir ürün olarak değerlendirme anlayışına dayalı, tüm paydaşlara (turistler, iş dünyası ve yerel bölge sakinleri) hitap eden bir yönetim stratejisi oluşturmaları önemlidir (Paskaleva-Shapira, 2007: 109). Destinasyon yönetimlerinin rekabet avantajı sağlamak adına kullanacakları en önemli araçlardan biri de kendilerine özgü olan kültürleridir (Therkelsen, 2003: 135). Yerel kültür aynı zamanda çoğu kişiyi seyahat etmeye yönelten motivasyon unsurlarındandır. Araştırma konusunun da temelini oluşturan ev restorancılığı kavramı destinasyonlar için kültürün tanitım aracı olarak ön plana çıktığı önemli bir yenilikçi hizmet türü olarak değerlendirilebilir.

Yeni turistik deneyim arayışında turistler için önemli bir fırsat olarak değerlendirilebilecek olan ev restorancılığının başarılı bir şekilde uygulanması ile destinasyonlarda birçok farklı kazanım elde edebilirler. Bu kazanımlar şu şekilde sıralanabilir (Şahin ve İdikut Şahin, 2020: 212);

-Öncelikle destinasyondaki çekicilik unsurlarına destek olabilecek bir turistik ürün çeşitlendirmesi sağlayabilir.

-Ev restorancılığı, destinasyonda turistlerin ziyaret ettikleri alanların genişlemesini sağlayabilir. Normalde turistlerin hiç girmediği bir sokağa veya alana bu hizmet sayesinde turistler çekilebilir.

-Turizm faaliyetleri içerisinde genellikle hediyelik eşya veya yerel üretim yiyecek ürünleri üreticisi olarak değerlendirilen ev kadınları için istihdam yaratabilecek yeni bir alan oluşabilir. 
- Bu hizmet türünün yaygınlaşmasıyla birlikte toplumda turist ve turizm bilincinin gelişmesi sağlanabilir.

-Ev restorancılığından faydalanan ziyaretçilerin yeni kültürleri tanımasına paralel olarak ev sahipleri ve yerel halk da farklı kültürler ile daha fazla etkileşime girebilir.

• Bu hizmet türünün yaygınlaşmasıyla örgütsel yapıdaki yiyecek-içecek işletmelerindeki rekabet ortamının ve hizmet kalitesinin artması sağlanabilir.

-Ev restorancılığının destinasyon için en önemli kazanımlarından birinin de destinasyonda ekonomik olarak bir katma değer yaratabileceğinden söz edilebilir.

\section{ARAŞTIRMANIN AMACI}

$\mathrm{Bu}$ araştırmanın amacı ev restorancılı̆̆ının bir turistik ürün olarak sunulması durumunda destinasyon kazanımlarını paydaş görüşleriyle birlikte ortaya koymaktır. Bu amaç doğrultusunda aşağıda yer alan sorulara cevap bulunması istenmektedir.

-Ev restorancilığı destinasyonlarda nasıl uygulanabilir?

-Ev restorancılığının destinasyon açısından kazanımları nelerdir?

\section{ARAŞTIRMANIN YÖNTEMİ}

Araştırmanın amacına uygun olarak konu ile ilgili destinasyon paydaşlarının görüşlerini derinlemesine elde edebilmek adına nitel araştırma yöntemlerinden görüşme tekniği kullanılmıştır. Nitel yöntemlerden en sık kullanılanı görüşmedir. Görüşme insanların perspektiflerini, tecrübelerini, duygularını ve algılarını ortaya koymada kullanılan oldukça güçlü bir yöntemdir (Yıldırım, 1999: 10). Araştırma kapsamında görüşme tekniğinin kullanılmasının en önemli sebebi araştırma konusunun hem teorik hem de uygulama bakımından yeni olarak nitelendirilebilecek bir konu olmasıdır. Soru formu hazırlanırken destinasyonlar açısından yerel halkın doğrudan üretim süreci içerisinde yer aldığı başka bir hizmet türü olan ev pansiyonculuğu ile ilgili yapılmış çalışmalardan (Akyol, 2012; Emir, 2018; Baysal, vd. 2019) yararlanılmıştır. Teorik olarak hazırlanan yarı yapılandırılmış mülakat sorularının uygulama aşamasında katılımcıların cevaplarına göre sonda soruları ile geliştirilmesi amaçlanmıştır.

Nitel araştırmaların yapısal özellikleri itibariyle evreni temsil etme gibi bir hedefi yoktur. Çalışma kapsamında örneklem belirlemek yerine araştırmanın amacına uygun veri toplanabilecek bir çalışma grubu (Bakioğlu ve Demiral, 2013: 13) kullanılmıştır. Bu sebeple çalışmanın uygulama alanı olarak kendine has karakteristik özelliğe sahip olan ve yeme içme kültürü açısından zengin olduğu düşünülen Van ili seçilmiştir. Dolayısıyla Van ilinde ev restorancılığının uygulanması konusunda karar verici konumdaki 3 yerel yönetim temsilcisi, 1 sektör temsilci, 1 sivil toplum kuruluşu temsilcisi ve 1 seyahat acenteleri birliği temsilcisinden oluşan bir çalışma grubu ile araştırma tamamlanmıştır. Araştırmanın uygulanması aşamasında öncelikle ev restorancılığı ile ilgili kavramsal olarak detaylı bilgiler verilmiştir. Kavramsal bilgiler ile birlikte dünyada uygulanan ev restorancılığı sistemi ile ilgili görsel çıktılar ile bilgilendirme desteklenmiştir. Katılımcıların konuyla ilgili yeterli bilgilere sahip olduklarını belirtmesi üzerine görüşme sorularına geçilmiştir.

Araştırma kapsamında yapılan uygulamanın tamamlanmasıyla birlikte toplanan sözlü veriler yazılı ortama aktarılmış ve veri çözümleme aşamasına geçilmiştir. Elde edilen verilerin çözümlenmesi için içerik analizi tekniğinden faydalanılmıştır. İçerik analizi, açık kodlama kurallarına dayanarak birçok metin kelimesini daha az içerik kategorisine sıkıştırmak için sistematik, tekrarlanabilir bir teknik olarak tanımlanmıştır (Stemler, 2001: 137). Elde edilen veriler üzerinde cevaplar içerisindeki kelimelerin sıklığı, eş değer kelimelerin kullanılması ve yorumların 
ortak yanları dikkate alınarak görüş birliği olan konular ve dikkat çeken farklılıklar sıralanarak bulgular oluşturulmuştur.

\section{BULGULAR}

Cevapların analiz edilmesiyle elde edilen soyut bulgular kategorize edilerek somutlaştırmaya çalışılmıştır. Aşağıda söz konusu kategoriler altında toplanan bulgular örnek cevaplar ile birlikte yer almaktadir.

\section{Görüş̧leri \\ Katılımcıların Destinasyon Ekonomisi Açısından Ev Restorancılı̆̆ı Hizmetine İlişkin}

Katılımcılar genel olarak bu hizmeti sağlayacak olan girişimcilerin bu süreçten ekonomik olarak tatmin edici bir kazanç elde edeceğini ve özellikle aile bütçesine katkıda bulunmak isteyen ev hanımları için ekonomik açıdan önemli bir fırsat olduğunu belirtmişlerdir. Bu somut bulgular aşağıda doğrudan aktarılan katılımcı cevaplarından çıkarılmıştır.

... Tabi bunun ekonomik açıdan kazanımı çok olur. En başta istihdam să̆lar daha fazla insan para kazanabilir. Burada önemli olan bir unsur da bu uygulamanın dönemlik olup olmayacă̆ıdır (K1).

... Önce ev hanımlarn kazanır sonra manaviyla marketiyle o mahalle kazanır sonra o şehir kazanır. Buradan kazanılan para şehrin her yerini etkiler (K4).

... Tabi ev ekonomisine ve çalışamayan kadınlara doğrudan katkı sağlayacaktır. Özellikle ev hanımları ve yemek yapmaktan hoşlanan her birey sürekli yaptıkları rutin bir işten para kazanma firsatı yakalayacaktır (K3).

Destinasyon ekonomisi içerisinde yeme içme kaynaklı gelirlerin artırılması açısından da ev restorancılığının diğer yiyecek içecek işletmeleri ile arasında bir rekabet oluşmasıyla ekonomik kazanımların oluşacağından bahsedilmektedir.

... Dolayısıyla bu tür bir hizmet sunmak ortaya bir yarış çıkaracağı için rekabet olacaktır. Rekabet de her zaman insanların kendine çeki düzen vermesini sağlar. Bu tür alternatiflerin olması insanlarn yeme içme konusunda daha fazla harcama yapmasına neden olacaktır (K1).

... Özellikle bizim gibi şehirlerde salaş yerlere olan rağbet, sokak yemekleri popüler olmaya başladı. Rekabet oluşacak çünkü Pazardaki rakip artınca pay düşecek ve iyi bir alternatif olacaktır. Her yeni açılan küçük bir işletme olsa bile büyük restoranları tehdit ediyor ev restoranlar da böyle olacaktır (K3).

...Ikisinin çok farklı olmadığını düşünüyorum. Dolayısıyla birbirlerini etkileyeceklerdir. Rekabet olursa yemeklerin kalitesi de artar sunumun şekli de artar. Menülerin daha özel olmasın sağlar (K5).

Katılımcılar aynı zamanda turizmden elde edilen gelirler bakımından ekonomik kazanımların artacağını belirtmektedir. Bu artışın kaynağı olarak ev restorancılığı sayesinde yerli ve yabancı turist sayısında artış olabileceğini göstermektedirler. Bu bulgulara ilişkin cevaplar şu şekilde aktarılmıştır.

... Birden fazla bu tür restoranlarn açllması yeni deneyimler arayan turistlerin bölgeye çekilmesini mutlaka să̆lar. İnsanlar yalnızca bu tür bir hizmet için bile buraya gelebilir (K1).

Yeni şeyler her zaman talep görür. Dolayısıyla turist sayısını da artırır diye düşünüyorum. Bu hizmeti alan kişiler bu durumu arkadaşına ailesine de anlatır. "Ahmet adında birinin evine akşam yemeği için gittim. Evini restoran olarak hizmete açmış çok güzeldi bence sizde gidin" diyebilir (K2). 
İnsanlar zaten böyle özel şeyler görmek istiyorlar. Böyle bir uygulamayla ziyaretçi sayısı kesinlikle artar (K4).

Mutlaka gelen ziyaretçi sayısına olumlu etkisi olacaktır. Özellikle ilk kez uygulandiğı için önemli bir çekicilik unsuru da olabilir (K6).

Ev restorancılığı hizmeti destinasyon ekonomisi açısından genel olarak değerlendirildiğinde katılımcıların bu tür bir uygulamanın ekonomik açıdan olumlu etkileri olacağını düşündükleri görülmektedir.

\section{Görüşleri \\ Katılımcıların Destinasyondaki İstihdam Açısından Ev Restorancılı̆̆ı Hizmetine İlişkin}

Katılımcılara göre ev restorancılığının en önemli kazanımlarından biri yaratacağı istihdam olarak değerlendirilmektedir. Ev restorancılığı ile ev hanımları için istihdam ortamının oluşmasının yanında aynı zamanda yemek yapmaktan keyif alan erkekler için de yeni bir iş fırsatının ortaya çıkacağı katılımcılar tarafından belirtilmektedir. Bu istihdamın yaratılması için de yerel halkın teşvik edilmesi ve gerçekleştirilmesi için yapılması gereken çalışmalar da katılımcılar tarafından aktarılmıştır. Bu bulgulara ilişkin katılımcı cevapları şu şekildedir.

Böyle bir uygulamanın ev hanımlarnna da yerel halkın diğger unsurlarına istihdam açısından katkı sağlayacă̆ını düşünüyorum. Fakat bu uygulamanın evlerde deŏil de yine ev hanımları ya da halkın diğer kesimleri tarafindan farklı mekanlarda uygulanmasının daha doğru olacă̆ın düşünüyorum (K1).

İstihdam yaratacağın kesinlikle düşünüyorum. Sadece ev kadınları değil burada kebap konusunda yemek konusunda erkekler de iyidir. Onlar da bunu yapar. Istihdam için insanlara bunu biz anlatabiliriz. Ya da böyle örnek uygulama alanlar yapanz turistler oraya geldikçe buradaki insanlarda bizde bunu yapalım diyebilir (K2).

...Ev kadınlarına istihdam sağlayabilir ama büyük ölçüde değil. Uygulanabilirliği kolay olmaz. Bu sebeple bunun uygulaması için kültür müdürlükleri tanıtım çalışmaları yapabilir (K3).

...İstihdam sağlayabilir. Aile bütçesine katkıda bulunmak isteyen fakat çocuklardan falan dışarıdan çalışamayan insanlar için iyi bir firsat. Tanıtımın birçok kanaldan yapabiliriz (K6).

Katılımcılar ev restorancılığı hizmetinin uygulanması için bir denetim sisteminin oluşturulması gerektiğini ve bunun için öncelikle eğitim sertifikaları ve programlarının oluşturulması gerektiğini ve bu belgeleri alan bireyler tarafından bu hizmetin gerçekleştirilmesi gerektiğini belirtmektedirler. Yerel halkın bu konuda hem istekli hem de çekingen kalabileceği de katılımcıların cevaplarından çıkartılan diğer bir bulgudur. Söz konusu bu bulgulara ilişkin cevaplar aşağıda yer almaktadır.

...Kadınlara yönelik pek çok kurs mevcut böyle bir programın da hayata geçirilmesi başarı için gereklidir. Şu an zaten geleneksel yemeklerin yapımını içeren kurs da mevcuttur. ...Yerel halkın yaklaşımının olumlu olacağın düşünüyorum fakat sistemin tam anlamiyla anlatılmasi gerekiyor (K1).

...Bir sertifika programı bunun için şarttır bence. Yerel halk da katılım sağlar diye düşünüyorum. Bunun eğitimi verilmeden yapılırsa sorunlar oluşur (K2).

Böyle bir hizmet için önemli bir altyapı çalışması gerekir bunun başında da eğitim gelir sertifikayla bu yapılabilir. Servis, hijyen, sunum eğitimleri verilebilir (K4).

...Sertifika programlar olmadan kontrollü bir durum olamaz zaten. Yerel halkı buna bu işleyişe hazırlamak gerekir katılım olur ama içeriği iyi anlatmak lazım (K5).

Katılımcıları cevapları genel olarak değerlendirildiğinde istihdam açısından ev restorancılığına ilişkin düşüncelerinin olumlu olduğu söylenebilir. İstihdam yaratma konusunda ev restorancılığının destinasyona katkı sağlanacağı düşünülmektedir. 


\section{Görüşleri \\ Katılımcıların Destinasyonun Yerel Kültürü Açısından Ev Restorancılı̆̆ı Hizmetine İlişkin}

Yerel kültür açısından ev restorancılığını değerlendirilmeleri istenen katılımcılar ev restorancılığının en önemli çıtılarının yerel kültür konusunda gerçekleşeceğini düşünmektedirler. Cevaplar genel olarak değerlendirildiğinde ev restorancllığının hem yerel kültürün daha görünür olmasının sağlanacağı hem de yerel kültüre çeşitli katkılar olacağını düşünmektedirler. Bu bulguların çıkarıldığı cevaplar şu şekildedir.

\section{... Medyada ya da dışarda ziyaret edilen yerin yüzde 20 si gözüküyor. Bununla} daha fazla kültür görünür. Yerel halkın turizme daha yakınlaşmasını să̆lar. Her şey tanıtımlarda kullanılmıyor. Bu kullanılmayan şeylerin de tekrar görülmesini să̆lar (K2).

...bu sistemin kontrol altında tutulmasıla birçok olumlu nitelikler olur. Mesela aile yapısı aile büyükleriyle aynı eve yaşanması gibi durumlar turistlere farklı gelebiliyor. Bunlarn nasıl olduğunu bu şekilde anlatabilirsiniz (K5).

Olumsuz etkisi olabileceğini düşünmüyorum kültürün tanıtılması turiste bir tatmin sağladığı gibi bize de kültürümüzü tekrar hatırlatacaktır. Unutulmuş yemekler elbiseler sunum aletleri gibi birçok kültürel öğe tekrar gün yüzüne çıkar (K6).

Katılımcılar yerel kültür açısında ev restorancılığı değerlendirirken aynı zamanda kültürler arası bir etkileşim gerçekleşeceğinden ve bu etkileşimin destinasyona yönelik ön yargıları yıkacağından ve kültürün tanıtılması için birçok fırsat sağlayacağından bahsetmektedirler. Bu çıkarımlar aşağıdaki cevaplardan elde edilmiştir.

Tabi ki yeni insanlar tanımak insanı geliştirir. Bunlar yabancı olursa kendi kültürümüzü daha doğru aktarabiliriz. Yerli turistlere de şehre karşı önyargıyı kırmak için bir firsat olur. Insanlar buradaki samimiyeti gördükçe tekrar gelmek isteyecektir (K1).

Yerel giysilerimizi doğrudan görebilirler. Misafiri nasıl ağırladiğımız ne şekilde ağırladığımız görülür bununla. Bizim insanlarımızda gelen insanlarda bir şeyler öğrenir, görür. Bu misafirperverlik turistleri bir daha getirir (K2).

Bu tür bir hizmet doğrudan bir kültürel etkileşim sağlayacaktır. Yedikleri yemekleri tatil sonrası kendi eolerinde yapmak isteyebilirler. Arkadaşlarna burada böyle bir hizmet var diye anlatabilir (K3).

Yerli halkta turiste ve turizme olan mesafeli duruşun böyle uygulamalarla yok olacağını düşünüyorum. Yeni insanlar tanımak her zaman iyidir. İnsanları bu şekilde bir araya getirerek aynı zamanda ön yargıların yıkılmasına da firsat tanını (K4).

Yerel kültürün daha görünür bir yapıya kavuşması, yerli halkın turizm hareketliliğine katılma oranının arttırılması ve yerel yaşam tarzının doğrudan aktarılması gibi konular ev restorancılığının destinasyon açısından en önemli kazanımları olarak görülmektedir.

\section{Görüşleri}

Katılımcıların Destinasyonun Tanıtımı Açısından Ev Restorancılı̆̆ı Hizmetine İlişkin

Katılımcılar ev restorancılığı ile birlikte ulusal veya uluslararası tanıtım çalışmalarında kullanılmayan birçok öğenin tanıtım unsuru olarak değerlendirilebileceğini düşünmektedirler. Destinasyonun kendine has özelliklerinin ev restorancılığı aracılığıyla daha samimi bir şekilde aktarılacağı katılımcı görüşlerinde belirtilmektedir. Bu çıkarımlara ilişkin cevaplar şu şekildedir.

... Kültürün tanıtılması için bu çok iyi bir firsattır. Bununla ilgili medyada böyle bir uygulama yaptığımızı anlatabiliriz. Festivalle, fuarlarda buna yer vererek anlatabiliriz. Bu yeni bir uygulama olacă̆ı için başarılı uygulanırsa ulusal olarak da uluslararası da tanıtımı olur. Otele gelen müşterilere buralar anlatılıp ziyaret etmesi să̆lanabilir. Restoranlarda garsonların sürekli yöresel giyecekle servis yapması pek mümkün değil ama ev restorancılı̆̆ ile bunlarda tamıtılabilir (K3). 
...Bundan daha güzel doğrudan tanıtım yapma şansı olamaz zaten. Giyimimizi evlerimizi masalarımı yeme içme tarzımızı daha iyi nasıl tanıtabiliriz (K4).

Tanıtım bu işin ekonomik katkısından daha önemlidir. Bu iş tanıtım açısından öncelikle yerel halkta turizm ve turist bilinci oluşturur. Insanlar yalnızca alışveriş merkezinde ya da cadde de gezmez mahalle aralarinda da bu tür restoranlarn olduğu yerleri gezmeye başlar. Bu da şehrin gerçek yaşamını tanıma ve tantma firsatı sağlar K5).

Katılımcılar destinasyon tanıtımı açısından ev restorancılığının sağlayacağı en önemli katkılardan birinin de destinasyondaki gastronomi varlığı açısından gerçekleşeceğini belirtmektedirler. Unutulan yiyecek ve içecek tariflerinin tekrar destinasyona kazandırılması, hiç bilinmeyen yöreye özgü yiyeceklerin bilinirliğinin sağlanması ve pişirme sürecinin nasıl gerçekleştiğini ziyaretçilere aktarabilme şansının olması önemli bulgular olarak görülmektedir. Söz konusu bulguların çıkarımlarının yapıldı̆̆ı cevaplar şu şekildedir.

Yemeği sunarken nasıl yapıldığın içinde ne olduğu ne zamandan beri bunu yaptığımızı anlatırız. Belki daha önce o yemekteki bir malzemeyi hiç yememiştir. Belki bazı yemekleri yaparken mutfă̆a çă̆ırııı misafirleri (K2).

Bu işin özü o olmalı zaten. Var olan yemekleri ve evlerde yapılan ama işletmelerde olmayan yemeklerin tanıtılması açısından çok önemli bir firsat. Hatta başka mahallede yapilan bir yemek bu mahalle de bile bilinmeyebilir. Bu bile bir farklilık yaratır (K4)

...Bizim mutfağımız en güçlü yanlarımızdan biri olduğu için yerli yeme içme ürünlerini tanıtmak için çok büyük firsat olur. Yeni neslin bile bilmediği sebzeler meyveler var turistler bunlar evden başka bir yerde göremez bizde bunlar böylelikle tanıtmış oluruz (K5).

Yöreye özgü yemekler açısından evlerde yapılış tarzlan ve lezzetleri restoranlara göre çok çok daha iyi. Evdeki kaliteyi bulmak imkânsız bu sebeple çok etkileyici bir tanıtım olacağın ve ziyaretçilerde çok önemli bir iz bırakılacağın düşünüyorum. Tanıtım aşamasında yemeklerin nasıl yapıldı̆̆ı konusu açısından bile çok önemli katkılar sağlayacaktır (K6).

Destinasyon tanıtımı açısından ev restorancılı̆̆ı genel olarak değerlendirildiğinde katılımcıların destinasyona önemli katkılar ortaya çıkacağını düşündükleri görülmektedir. Destinasyonun tanıtımının yiyecek ve içeceklerin özelinde ev restorancılığı aracılığıyla daha güçlü bir şekilde gerçekleşeceği de belirtilebilir.

Yukarıdan yer alan bulgulara ek olarak katılımcılar ev restorancılığının uygulanması aşamasında yasal altyapının tam ve sağlıklı bir biçimde oluşturulması ve denetim konusunun ciddi tutulması gerektiği konusunda tamamen görüş birliği içerisinde oldukları da belirtilebilir.

\section{SONUÇ}

$\mathrm{Bu}$ çalışmada destinasyonda karar vericilerin yeni bir hizmet yaklaşımı olarak değerlendirilebilecek ev restorancılığına ilişkin düşüncelerini ortaya koyarak ev restorancılığının destinasyon tanıtımı açısından değerlendirilmesi amaçlanmıştır. Ev restorancılığı ile ilgili yapılmış akademik bir çalışmaya rastlanılmaması sebebi ile araştırma bulgularının karşılaştırmasının yapılması mümkün değildir. Bu sebeple bu bölümde yalnızca bu araştırmadan elde edilen bulgular yorumlanmıştır. Araştırmadan elde edilen bulgulara göre ev restorancılığının özellikle destinasyon tanıtımı açısından birçok firsatlar sunduğunu belirtmek mümkündür. Diğer bir deyişle ev restorancilığının destinasyon tanıtımı sürecinde kullanılabilecek önemli araç olduğundan bahsedilebilir.

Çalışmanın bulguları değerlendirildiğinde sonuçları madde halinde sıralamak çıktıları somutlaştırmak adına daha fazla katkı sağlayabilir. Buna göre çalışmanın sonuçları şu şekilde siralanabilir; 
-Yerel yaşam örneğini ve mekanlarını doğrudan deneyimleme fırsatı sunması açısından ev restorancılığı turistlere heyecan verici bir hizmet olarak sunulabilir.

-Yerel halkın turizm hareketliliği içerisinde daha fazla rol alması sağlanabilir.

-Yerel yiyecek ve içecekler üzerine kurgulanan hizmet olması nedeniyle bu kültürün korunması hatta unutulan tariflerin tekrar gün yüzüne çıarılması söz konusu olabilir.

- Yemeklerin kendine özgü pişirme teknikleri varsa (tandır vb.) bunların ziyaretçilerin önünde ya da görebilecekleri bir yerde sergilenmesi sağlanarak ziyaretçilerin de sürece katılımının sağlanması deneyim hazzını artırabilir.

-Atıl iş gücü durumunda bulunan ev hanımlarının ekonomik alan içerisine dahil olmasına olanak tanıyan ev restorancılığı aynı zamanda rekabet ortamının artmasıyla diğer yiyecek içecek işletmelerinin de hizmet kalitelerini artırmaları konusunda teşvik edecektir.

- Aynı zamanda ev restoranları aracilığıyla normal bir seyahat sırasında turistler tarafından girilmeyen mahalle ve sokaklara girilmesiyle destinasyonun seyahat alanları genişleyecektir.

Çalışma bulgularına göre ortaya çıkan diğer sonuçlar ise ev restorancılığının uygulanması konusunda yapılması gerekenleri ifade eden sonuçlardır. Buna göre;

-Destinasyon yöneticileri ev pansiyonculuğunda olduğu gibi bu tür yerlerin de sertifikaya bağlı olarak açılmasına müsaade etmeli ve denetlemelidir.

-Mimari olarak da kültürün ya da destinasyonun tanıtılmasını sağlayacak evler bu süreçte öncelikli olarak belirlenmelidir.

-Ev restorancılığını uygulayacak ev hanımları teknik eğitim ile desteklenerek ziyaretçilerin sorun yaşamadan daha memnun bir şekilde bu deneyimi yaşamaları sağlanmalıdır.

Çalışma genel olarak değerlendirildiğinde, ev restorancılığının destinasyona ekonomik değer katacağı, istihdam yaratacağı, yerel kültürün korunmasını sağlayacağı ve önemli bir destinasyon tanıtım aracı olabileceği söylenebilir. Bu çalışmanın devamında ev restorancılığını deneyimleyen kişilerin görüşleri ya da ev restorancılığı girişimini gerçekleştiren kişilerin konuyla ilgili düşüncelerinin ortaya konması araştırmacılara öneri olarak sunulabilir.

\section{Kaynakça}

Akyol, C. (2012). Kirsal Turizmde Ev Pansiyonculuğu Modeli ve Karadeniz Örneklemesi Artvin, International Journal of Social and Economic Sciences, 2(2), 79-83.

Bakioğlu, A., ve Demiral, S. (2013). Okul Yöneticilerinin Belirsizlik Durumlarını Algılama ve Karar verme Tarzları. Eğitim Bilimleri Dergisi, 38, 9-35.

Baysal, K., Alkan, Ö., \& Ok, S. (2019). Ev Pansiyonculuğunun Kırsal Turizme Katkısı: Datça Örneği, Uluslararası Kırsal Turizm ve Kalkınma Dergisi (IRTAD) E-ISSN: 2602-4462, 3(2), 60-68.

Benur, A. M. ve Bramwell, B. (2015). Tourism Product Development and Product Diversification in Destinations. Tourism Management, 50, 213-224. 
Echtner, C. M. (2010). Paradise Without People: Exclusive Destination Promotion. Tourism Culture \& Communication, 10(2), 83-99.

Emir, G. (2018) Amasra'da Ev Pansiyonculuğu Algısı ve Uygulama Sorunları, Doktora Tezi, İzmir: Dokuz Eylül Üniversitesi, Sosyal Bilimler Enstitüsü.

Farmaki, A. (2012). A Supply-Side Evaluation of Coastal Tourism Diversification: The Case of Cyprus. Tourism Planning \& Development, 9(2), 183-203.

Gordin, V. ve Trabskaya, J. (2013). The Role of Gastronomic Brands in Tourist Destination Promotion: Thecase of St. Petersburg. Place Branding and Public Diplomacy, 9(3), 189-201.

Grigorova, Z. (2016). Diversification of Tourist Product-Hisarya Municipality. New Knowledge Journal of Science, 5(1), 11-16.

Karapınar, M. (2013). Kuzeydoğu Anadolu Turizm Destinasyonu Tanıtım Markalaşma Araştırması. Kuzeydoğu Kalkınma Ajansı, Erzurum. Erişim Tarihi: 22.12.2018

Khan, Y. ve Karaoulanis, A. (2018). Innovative Destination Promotion Strategies: The Cornerstone of The Developing Countries Struggle towards Growth. International Journal of Management \& Information Technology, 13(1), 3188-3192.

Kılıç, B. ve Kurnaz, A. (2010). Alternative Tourism and Ecological Farms on Creating Diversification of Tourism Product: Example of Pastoral Valley. Journal of Business Research-Turk, 2(4), 39-56.

Kim, J., Jun, J., Park, E. ve Lee, C. K. (2018). Investigating Public Relations as a Destination Promotion Strategy: The Role of Multiple Dimensions of Publicity. Journal of Travel \&Tourism Marketing, 35(5), 583-594.

Paskaleva-Shapira, K. A. (2007). New Paradigms in City Tourism Management: Redefining Destination Promotion. Journal of Travel Research, 46(1), 108-114.

Purnomo, A., Wiradimadja, A., \& Kurniawan, B. (2019, March). Diversification of Tourism Product in KSPN Ijen. In IOP Conference Series: Earth and Environmental Science, 243 (1), 012079.

Rotich, D., Nthiga, R., Bor, T. ve Kogola, B. (2012). Product Diversification for Sustainable Tourism Development: Exploring The Strenghts and Challenges of Kisumu Region, Kenya. European Journal of Business and Social Sciences, 1(9), 108-117.

Sheehan, L., Ritchie, J. B., ve Hudson, S. (2007). The Destination Promotion Triad: Understanding asymmetric Stakeholder interdependencies Among The City, Hotels, and DMO. Journal of Travel Research, 46(1), 64-74.

Stemler, S. (2001). An Overview of Content Analysis. Practical assessment, Research \& Evaluation, 7(17), 137-146.

Şahin, S. ve İdikut Şahin, S. (2020). Destinasyon Tanıtımında Hizmet Yeniliği Olarak Ev Restorancılığı, Sosyal, Beşeri ve İdari Bilimler Alanında Akademik Çalışmalar-2 İçinde Bölüm. Ed.Hasan Selim Kıroğlu Gece Kitaplığ1

Therkelsen, A. (2003) Imagining Places: Image formation of Tourists and İts Consequences for Destination Promotion, Scandinavian Journal of Hospitality and Tourism, 3:2, 134-150,

Yıldırım, A. (1999). Nitel Araştırma Yöntemlerinin Temel Özellikleri ve Eğitim Araştırmalarındaki Yeri ve Önemi. Eğitim ve Bilim Dergisi, 23(112), 7- 17.

\section{İnternet Kaynakları}

Dineaway (2018) Https:// Dineaway.Net/About-Dineaway/ 